\title{
De beheersing van de (kosten van) accountantscontrole in Nederland
}

\section{Inleiding}

Het accountantsberoep heeft zich de laatste decennia ontwikkeld van een sterk persoonsgebonden beroep naar een ondernemingsgewijze dienstverlening, waarbij naast grote multinationaal georganiseerde kantoren middelgrote en kleine kantoren voorkomen die alle een gevarieerd pakket van diensten aanbieden. Door de vermaatschappelijkingstendenzen in het bedrijfsleven heeft de accountant, evenals de arts, de notaris, de dominee, de pastoor, en anderen zijn 'heilige' huisje moeten verlaten. Daarnaast heeft hij zijn diensten, in concurrentie met andere accountants en adviesorganisaties moeten gaan aanbieden. Naast een vermaatschappelijking is er een verzakelijking binnen het accountantsberoep ontstaan. Dit beroep wordt heden ten dage dan ook geconfronteerd met een stijgende belangstelling en een toenemende kritiek. Deze kritiek heeft in hoofdzaak te maken met problemen die zowel zijn voortgesproten uit de structuur van het beroep als uit de uitoefening ervan. Een van de kritiekpunten, zowel nationaal als internationaal, betreft de ondoorzichtigheid en de hoogte van de accountantskosten die in rekening worden gebracht voor de verrichte accountantsdiensten. Dat deze kritiek in belangrijke mate afkomstig is van het management moge geen verwondering wekken. Het management, verantwoordelijk voor een rendabele bedrijfsvoering, zal regelmatig de samenstelling van de kosten van zijn onderneming aan een kritisch onderzoek onderwerpen. Extra kritisch zullen daarbij de kosten worden beschouwd die niet direct ten behoeve van de primaire functie-uitoefening worden gemaakt. Het gaat daarbij om de management-afhankelijke kosten ('discretionary costs'). Een kenmerk van management-afhankelijke kosten is dat een objectieve bepaling van het niveau ervan niet mogelijk wordt geacht (Beylevelt en Vlotman, 1985). Deze categorie van kosten heeft in hoofdzaak betrekking op indirecte 'overhead' activiteiten.

Tot de kosten waarop het management tot voor kort geen of nauwelijks invloed heeft gehad, maar eigenlijk wel zou moeten hebben, kunnen de kosten van de accountantscontrole worden gerekend.

In het kader van de beheersing van de management-afhankelijke kosten begint men in het Nederlandse bedrijfsleven sterker dan voorheen aandacht te besteden aan de beheersing van de accountantscontrole en met name 
aan het kostenaspect daarvan. De afstoting c.q. taakverandering - omzetting van de certificerende taak in 'operational audit' - van de interne accountantsafdeling (IAD) bij een aantal ondernemingen en het organiseren van cursussen en eendagsseminars over het desbetreffende onderwerp zijn daarvan indicaties.

In dit artikel wordt vanuit de optiek van de ondernemingsleiding de problematiek van de beheersing van de accountantscontrole en de accountantskosten benaderd. Er wordt daarbij van uitgegaan dat de accountantscontrole een produkt ('commodity') is. Consequentie van dit uitgangspunt is dat het contact tussen ondernemingsleiding en accountant in feite een marktgebeuren is tussen twee ondernemingen. Niet alleen in de literatuur (Francis, Simunic, Gilling en Stanton, en anderen) maar ook in de praktijk, met name bij ondernemingsleidingen (zie FINEM-nota's) zijn aanzetten voor dit uitgangspunt te vinden.

Allereerst worden in paragraaf 2 de aard van de controlewerkzaamheden en de rol van de externe accountant bij drie onderscheiden categorieën ondernemingen besproken. In paragraaf 3 wordt een overzicht gegeven van de factoren die de hoogte van de accountantskosten en de omvang van de controlewerkzaamheden kunnen beïnvloeden en van de relaties tussen beide. Vervolgens worden in paragraaf 4 de instrumenten waarover de ondernemingsleiding beschikt om de accountantskosten te kunnen beheersen behandeld. In paragraaf 5 worden enkele resultaten van een empirisch onderzoek naar de huidige stand van zaken met betrekking tot de wijze waarop de beheersing van de (kosten van) accountantsonderzoek binnen het $\mathrm{Ne}$ derlands bedrijfsleven gestalte heeft gekregen, weergegeven.

\section{De aard van de (controle)werkzaamheden en de rol van de externe accountant}

De werkzaamheden die de accountant voor een onderneming kan vervullen kunnen worden gesplitst in:

$a$ de algemene controle;

$b$ de specifieke opdrachten zoals bijvoorbeeld advisering op een bepaald gebied.

De algemene controle vloeit voort uit de behoefte van het maatschappelijk verkeer aan verklaringen van getrouwheid bij financiële verantwoordingsverslagen. Het gaat daarbij dan in hoofdzaak om de verklaring van de accountant bij de jaarrekening. Voor alle rechtspersonen waarop titel 8 Boek $2 \mathrm{BW}$ van toepassing is - uitgezonderd de kleine rechtspersonen - is een verklaring bij de jaarrekening wettelijk verplicht.

De algemene controle van de accountant valt uiteen in drie delen:

1 de verklaring bij de jaarrekening;

2 de melding van onvolkomenheden betreffende het functioneren van de onderneming in al haar facetten, voor zover dit uit de controle is gebleken;

3 het doen van aanbevelingen met betrekking tot de gesignaleerde problemen, in het bijzonder die op het terrein van de administratieve organisatie en de interne controle. 
Uit hoofde van zijn deskundigheden kan de externe accountant diverse diensten op financieel-economisch gebied aanbieden. Deze diensten kunnen variëren van administratieve dienstverlening tot meer algemene management-consulting activiteiten.

De rol van de accountant zal verschillen al naar gelang de omvang van de onderneming. Ten aanzien van die omvang kan het beste worden aangesloten bij de indeling van titel 8 Boek 2 BW.

In het algemeen zullen de werkzaamheden van de externe accountant zich bij grote ondernemingen in hoofdzaak beperken tot de algemene controle en het afgeven van een verklaring bij de (groeps)jaarrekening. De advieswerkzaamheden en de andere vormen van dienstverlening zullen veelal in mindere mate plaatsvinden, daar deze grote ondernemingen in het algemeen zelf over de nodige deskundigheden op deze gebieden beschikken. De grote ondernemingen hebben vaak een concernstructuur. Ten aanzien van de algemene controle doet zich het vraagstuk voor bij welke jaarrekeningen de ondernemingsleiding een accountantsverklaring wenst:

$a$ een verklaring bij de groepsjaarrekening van het concern als geheel, waarbij beurtelings enkele dochter- en/of groepsmaatschappijen, voorzover dat noodzakelijk is voor het oordeel over de groepsjaarrekening, worden gecontroleerd (de top-down benadering);

$b$ een verklaring bij de jaarrekening van elke dochter-en/of groepsmaatschappij en bij de groepsjaarrekening (de bottom-up benadering).

$\mathrm{Bij}$ de middelgrote ondernemingen is de rol van de accountant veelal zowel een controlerende als een adviserende. De laatste in hoofdzaak met betrekking tot die gebieden waarop de desbetreffende onderneming niet in huis kan beschikken over deskundigen. Bij de kleine ondernemingen, waar de controle van de jaarrekening wettelijk (nog) niet verplicht is, zal de accountant veel meer de rol van totaal-adviseur vervullen. Juist de adviesfunctie bij deze ondernemingen is belangrijk. De controlefunctie heeft bij deze ondernemingen een minder sterk accent dan bij de beide andere categorieën.

Onder de accountantskosten worden verstaan de kosten die voortvloeien uit de jaarlijkse controlewerkzaamheden betreffende de jaarrekening. De kosten die het gevolg zijn van andere accountantswerkzaamheden, zoals bijvoorbeeld advisering en administratieve dienstverlening, blijven in het hierna volgende buiten beschouwing.

\section{Factoren die de hoogte van de accountantskosten en de omvang van de controlewerkzaamheden kunnen beïnvloeden}

De kosten van accountantscontrole bestaan uit een prijs- en een hoeveelheidscomponent. De prijscomponent is te beschouwen als een resultante van vraag en aanbod op een markt. In het onderhavige geval is dit de markt van accountantsdiensten, in casu de accountantscontrole. Omtrent de structuur van deze markt in Nederland is nog weinig bekend. De vraag naar accountantscontrole wordt in belangrijke mate bepaald door wettelijke voorschriften. Aan de aanbodzijde staan naast een beperkt aantal grote accountantskantoren een relatief groot aantal kleine kantoren. Uit tabel 
3.1 blijkt (IAB, p. 10) dat de accountantscontrole voor ter beurze genoteerde ondernemingen geconcentreerd is bij een beperkt aantal grote accountantskantoren. Uit dit overzicht kan een voorzichtige conclusie worden getrokken dat de markt van de wettelijk verplichte accountantscontrole in Nederland (met betrekking tot de ter beurze genoteerde ondernemingen) die van een oligopolie is. ${ }^{1}$

Tabel 3.1: Concentratie van de accountantscontrole van ter beurze genoteerde ondernemingen in Nederland

\begin{tabular}{|c|c|c|c|c|}
\hline \multirow[b]{3}{*}{ Accountantskantoren } & \multicolumn{4}{|c|}{ Aantal ondernemingen } \\
\hline & & & & \\
\hline & $\mathrm{n}$ & $\%$ & $\mathrm{n}$ & $\%$ \\
\hline Grote vijf & 123 & 85,4 & 114 & 85,1 \\
\hline Kleine (9 kantoren) & 17 & 11,8 & 17 & 12,7 \\
\hline Buitenlandse ( 3 resp. 2 kant.) & 4 & 2,8 & 3 & 2,2 \\
\hline Totaal & $\overline{144}$ & 100 & 134 & 100 \\
\hline
\end{tabular}

In de Angelsaksische literatuur zijn in de laatste jaren regelmatig resultaten gepubliceerd van empirisch onderzoek naar de factoren die een verklaring voor de hoogte van de accountantskosten kunnen vormen en naar de relaties tussen deze mogelijke verklarende factoren (Hopgood \& Sciarrino, 1972a en b; Briston \& Perks, 1977; Miller, 1978; Simunic, 1980; Garner, 1980; Taylor \& Baker, 1981; Pound \& Francis, 1981; Lothian, 1983; Wallace, 1984a en b; Francis, 1984).

Voor Nederland heeft een dergelijk onderzoek nog niet plaatsgehad, echter wel een aanzet daartoe in een beperkte vorm.

Uit bovengenoemde Angelsaksische onderzoeken kan worden afgeleid dat de factoren die de hoogte van de accountantskosten kunnen bepalen in drie groepen uiteenvallen (Pound \& Francis, p. 360):

a algemene factoren;

$b$ ondernemingsbepaalde factoren;

$c$ accountantsbepaalde factoren.

Aan elk van deze drie factoren wordt hieronder een beschouwing gewijd.

\section{Algemene factoren}

Tot de algemene factoren worden naast de gang van zaken betreffende de nationale economie, de mate van regelgeving op het terrein van de verslaggeving en de accountantscontrole in het desbetreffende land gerekend. In het algemeen mag worden verondersteld dat de gang van zaken betreffende de nationale economie een vrijwel gelijke invloed heeft op de individuele onderneming. Ook voor de mate van regelgeving geldt dat het effect op de hoogte van de accountantskosten voor het merendeel van de ondernemingen veelal dezelfde is, zij het dat dezelfde regelgeving voor verschillende ondernemingen verschillende gevolgen kan hebben. Desalniettemin kunnen diverse elementen in de regelgeving van invloed zijn op de accountantskosten van bepaalde ondernemingen. Deze elementen betreffen onder meer de ondernemingsgrootte, de juridische structuur van de onderneming, de branche waarin de onderneming opereert, en dergelijke. Over de kosten die door de regelgeving worden veroorzaakt is in ons land nog weinig bekend. ${ }^{2}$ 


\section{Ondernemingsbepaalde factoren}

De ondernemingsbepaalde factoren zijn in belangrijke mate maatgevend voor de omvang van de controlewerkzaamheden van de accountant en daarmee bepalend voor de hoeveelheidscomponent van de accountantskosten.

In veel studies waarin de structuur van de accountantskosten aan een onderzoek is onderworpen is men uitgegaan van tamelijk eenvoudige relaties. Bij deze, veelal beschrijvende studies, gaan de onderzoekers ervan uit dat er een relatie bestaat tussen de hoogte van de accountantskosten en hetzij de omzet (Hopgood \& Sciarrino, 1972a en b, Briston \& Perks, 1977, Miller, 1978, Garner, $1980^{3}$ ), hetzij de totale activa (Gilling \& Stanton, 1978) hetzij één of andere combinatiemaatstaf van omzet en activa (Bavishi

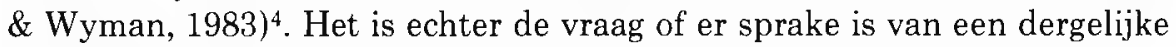
eenvoudige relatie. Immers in het geval dat een stijging van de omzet uitsluitend wordt veroorzaakt door prijsstijgingen van één of meer van de produktiefactoren (zoals grondstoffen, lonen, en dergelijke) dan zouden volgens voornoemde onderzoekers de accountantskosten evenzeer stijgen. $\mathrm{Nu}$ kan hiervan in het geval de kosten van de arbeid stijgen nog wel worden uitgegaan daar de beloning van het personeel van het accountantskantoor in het merendeel van de gevallen eveneens zal zijn gestegen. Mochten echter alleen de grondstoffenprijzen zijn gestegen dan lijkt een stijging van de accountantskosten minder voor de hand te liggen omdat hoogst waarschijnlijk de werkzaamheden van de accountants hierdoor niet zullen toenemen. Ook de relatie tussen accountantskosten en de waarde van de totale activa lijkt niet voor de hand te liggen. Verschillen in waarderingsgrondslagen voor de activa zouden dan van invloed zijn op de hoogte van de accountantskosten. In het geval van prijsstijgingen zal een onderneming die de activa op basis van de vervangingswaarde waardeert een hogere rekening voor accountantscontrole ontvangen dan een vergelijkbare onderneming die de activa op historische uitgaafprijs waardeert.

Een meer gecompliceerde relatie tussen de accountantskosten en ondernemingskarakteristieken ligt voor de hand.

De hoogte van de accountantskosten is sterk afhankelijk van de mate van complexiteit van de controle-opdracht. Daarbij spelen de volgende factoren een rol (Huys, 1983, p. 52):

- de omvang en diversiteit van voorraden en debiteurenbestanden;

- de aard en de structuur van de onderneming;

- de kwaliteit (toegankelijkheid) van de bedrijfsadministratie en de mate waarin eigen mensen beschikbaar kunnen worden gesteld voor de ondersteuning van de accountant bij diens controlewerkzaamheden.

In hun studie naar de markt voor accountantsdiensten in Australië geven Pound and Francis (p. 360), als onderdeel van een verklarend model voor de accountantskostenfunctie, een - niet uitputtende - lijst van ondernemingsbepaalde factoren die de hoogte van de accountantskosten beïnvloeden. Zij noemen het systeem van interne controle, het volume van de transacties, het type transacties, de organisatorische structuur, de financiële structuur, de produktiekarakteristieken, en de 'accounting-policies'. 
Verschillende andere - hoofdzakelijk Angelsaksische - schrijvers hebben getracht langs empirische weg, waarbij zij hebben gebruik gemaakt van multi-variate analyses, vast te stellen welke ondernemingskarakteristieken de hoogte van dan wel de verschillen tussen de accountantskosten van ondernemingen kunnen verklaren.

Het voert voor dit artikel te ver om uitgebreid in te gaan op deze onderzoeken. Hoewel er bij de verschillende onderzoeken sprake is van een verschil in methodologische aanpak en van gevonden relaties blijkt dat er ten aanzien van een aantal ondernemingsbepaalde factoren sprake is van overeenstemming. Het zijn vooral de ondernemingsg rootte, de complexiteit van de onderneming (gemeten naar het aantal dochtermaatschappijen) en de identiteit van de accountant. ${ }^{5}$

Opvallend is dat in relatief weinig van deze onderzoeken expliciet de aanwezigheid in de onderneming van een interne accountantsdienst als een mogelijk bepalende factor voor de hoogte van de (externe) accountantskosten voorkomt. Wallace (1984b) neemt in haar model de totale uitgaven voor de interne accountantsdienst op. Simunic is een van de weinige onderzoekers die expliciet rekening houdt met de kosten van de IAD.

\section{Accountantsbepaalde factoren}

De accountantsbepaalde factoren zijn in belangrijke mate maatgevend voor de prijscomponent van de accountantskosten.

De kosten die door een accountantskantoor aan zijn cliënten in rekening worden gebracht zijn samengesteld uit het aantal gewerkte uren en het daarbij behorende uurtarief. Het aantal gewerkte uren houdt nauw verband met de organisatie van de controlewerkzaamheden. Ten aanzien van de controlewerkzaamheden binden de gedrags- en beroepsregels (GBR) elke registeraccountant aan een minimum-prestatieniveau (deugdelijke grondslag, goed werk: artikel 11, Frielink, 1984, p. 36-37). Dit niveau kan evenwel niet zodanig worden gespecificeerd dat daaruit een standaard voor elke controle kan worden afgeleid, doch wordt in de praktijk overgelaten aan het professionele oordeel van de registeraccountant. Bij de invulling van de controlewerkzaamheden spelen de ondernemingsspecifieke factoren (zie boven) een grote rol. Daarnaast zijn er factoren die accountantskantoor specifiek zijn, zoals de samenstelling en ervaring van het controleteam, de mate van specialisatie (naar branche, naar aard der werkzaamheden, bijv. EDP-audit, en dergelijke). Ook een goede planning van de controlewerkzaamheden is van belang. Met behulp van een planning kan worden vastgesteld welke controlewerkzaamheden op welk moment moeten worden verricht, welke administratieve documenten in welke vorm door de onderneming dienen te worden verstrekt, en dergelijke. Een goede planning van zijn werkzaamheden stelt de controlerende accountant in staat de algemene controle te budgetteren, waardoor het mogelijk is dat budgetoverschrijdingen tijdig worden gesignaleerd en met de opdrachtgever kunnen worden besproken.

Aan specialisatie en differentiatie van de accountantswerkzaamheden kunnen kostenvoordelen verbonden zijn. Een van de mogelijkheden daarbij is de branche-gewijze groepering van controle-teams. 
In het FINEM-rapport Beheersing van (kosten van) accountantscontrole wordt opgemerkt (p. 20) dat het marktmechanisme voor accountantsdiensten onvoldoende werkt om een acceptabele prijs/kwaliteit-verhouding te waarborgen. Inzicht in de organisatiestructuur en in de tariefsstructuur en tariefsopbouw van het accountantskantoor vormen middelen waarmee de prijs/kwaliteit-verhouding van de accountantsdiensten - in casu de controle - door de ondernemingsleiding kan worden beoordeeld. Dit inzicht is voor de afnemer van de accountantsdiensten zinvol om zich een oordeel te kunnen vormen omtrent het efficiënt werken van dit kantoor. Beheersing van de kosten van zijn kantoor door de accountant zelf is een belangrijke voorwaarde om tot een aanvaardbare tariefstelling te komen. In dit verband dient wel te worden bedacht dat in het tarief een opslag voor de risico's uit hoofde van de beroepsaansprakelijkheid kan zijn begrepen.

Ook is het aan te bevelen dat de accountantskantoren hun (potentiële) klanten, meer dan voorheen het geval was, inzicht geven in de structuur en de opbouw van de controletarieven. In paragraaf 5 wordt hierop nader ingegaan.

\section{Instrumenten die de ondernemingsleiding ter beschikking staan om de accountantskosten te beheersen}

De keuze van het accountantskantoor is een factor die mede bepalend kan zijn voor de hoogte van de accountantskosten. Op grond daarvan kan het nodig zijn deze keuze periodiek aan een evaluatie te onderwerpen, niet omdat de persoonlijke band en de vertrouwensrelatie met de accountant ter discussie staan maar enkel en alleen om vast te stellen of de keuze van destijds nu nog de beste is. Dit kan vooral van belang zijn voor ondernemingen die een behoorlijke groei hebben doorgemaakt en nog steeds doormaken. Een kleine, lokaal opererende onderneming heeft er veelal uit kostenoverwegingen en een meer persoonlijke benadering door de accountant baat bij de controlewerkzaamheden op te dragen aan een klein regionaal kantoor. Bij grote internationaal opererende ondernemingen, met veel vestigingen in het buitenland, zal de ondernemingsleiding zijn aangewezen op één van de grote accountantskantoren die een breed scala van diensten aanbieden en meestal onderdeel vormen van een internationaal samenwerkingsverband. ${ }^{6}$

Wanneer uit bovenstaande evaluatie blijkt dat het voor de onderneming gewenst is de controle te laten verrichten door een ander accountantskantoor dan zou de ondernemingsleiding kunnen overwegen bij een aantal accountantskantoren een offerte aan te vragen gevolgd door bureaupresentaties. Bij deze offertes en bureaupresentaties is het van belang dat de desbetreffende accountantskantoren onder meer aandacht besteden aan de in de vorige paragraaf besproken accountantsbepaalde factoren, waarbij met name te denken valt aan de organisatiestructuur van het kantoor, aan de samenstelling en deskundigheid van het controleteam, aan de structuur en opbouw van de controletarieven en aan aspecten als branche-specialisatie en produkt-differentiatie. ${ }^{7}$ 
Opgemerkt moet evenwel worden dat het in Nederland, in tegenstelling tot bijv. de USA, (nog) niet gebruikelijk is bij andere accountantskantoren offertes aan te vragen voor de te verrichten accountantscontrole.

De instrumenten die de ondernemingsleiding kan hanteren ter beheersing van de accountantscontrole en de accountantskosten zijn eenvoudig en in feite voor de hand liggend. Het komt neer op de plannings- en beheersingscyclus die bij andere kostensoorten wordt toegepast.

Allereerst zal de besluitvorming met betrekking tot de opdracht aan de accountant dienen te worden geregeld, waarbij nadat de desbetreffende beslissing is genomen, de opdracht expliciet wordt gemaakt en met behulp van de 'engagement letter' schriftelijk wordt vastgelegd. Hiermee kan tevens worden voorkomen dat de controlewerkzaamheden van de accountant geruisloos overgaan in de adviestaak. Opdrachten voor advieswerkzaamheden en bijzondere opdrachten dienen afzonderlijk te worden afgesproken en afzonderlijk van de controlewerkzaamheden te worden gedeclareerd. Vervolgens is een planning van de accountantswerkzaamheden en een budgettering van de accountantskosten onontbeerlijk. In de planning - die te zamen met de controlerende accountant wordt opgesteld - worden de werkafspraken neergelegd. Onderdeel van deze planning is een tijdsschema. Het is gewenst dat de accountant een budget verstrekt waarin de kosten zijn gedetailleerd naar aard van de controle-activiteiten, naar dochtermaatschappijen, en andere. Betreffende de budgettering is tevens van belang daarbij goede procedure-afspraken te maken inzake de wijze van handelen indien zich budgetoverschrijdingen voordoen. Een evaluatie na afloop van de controlewerkzaamheden op basis van een nacalculatie in vergelijking met het budget vormt het sluitstuk van de beheersingscyclus met betrekking tot de (kosten van) de accountantscontrole.

Vanzelfsprekend vindt het gehele plannings- en beheersingsproces plaats op basis van een goede samenwerking tussen ondernemingsleiding en controlerend accountant.

In het kader van de beheersingsproblematiek van de accountantskosten dient ook aandacht te worden geschonken aan de interne accountantsdienst (IAD).

De werkzaamheden van interne accountants kunnen een zeer pluriform karakter hebben. In Nederland zijn er dienaangaande twee hoofdstromingen te onderscheiden:

a de interne accountant die tot taak heeft de interne jaarrekening te controleren ('financial audit');

$b$ de interne accountant die tot taak heeft de interne procedures te controleren ('operational audit') en soms zelfs de effectiviteit en efficiëntie van bepaalde processen ('operations audit').

Deze hoofdstromingen zijn niet exclusief en elkaar uitsluitend. Niet elke onderneming zal in de regel een IAD hebben, bijv. bij de kleinere ondernemingen zal op grond van onder andere kostenoverwegingen een IAD veelal niet aanwezig zijn. Daarentegen zal de interne accountantsfunctie bij bepaalde typen ondernemingen (bijv. banken, verzekeringsmaatschappijen), gezien de aard van het primaire proces, noodzakelijk zijn.

In het kader van de beheersing van de accountantskosten kan de functie 
van de interne accountant op twee wijzen worden beschouwd (Bak c.s., p. 30, e.v.):

1 als instrument in het beheersingsproces;

2 als object van het beheersingsproces.

De wijzen waarop een interne accountant of de IAD aan de beheersing van de accountantskosten kunnen bijdragen zijn:

$a$ als coördinator tussen de ondernemingsleiding en de externe accountant;

$b$ in een tegenwichtfunctie vanuit de eigen organisatie ten opzichte van de externe accountant;

c als bewaker van het systeem van interne controle;

$d$ als substituut voor (een deel van) de werkzaamheden van de externe accountant;

De instrumenten die de ondernemingsleiding ter beschikking staan om de kosten van de IAD te beheersen zijn dezelfde als die ten aanzien van de kosten van de externe accountant (zie hiervoor).

Een aspect waaraan de ondernemingsleiding in het kader van de beheersing van de accountantskosten aandacht kan besteden is dat van de toetsing van de declaratie. De ondernemingsleiding toetst zijn beleid op geregelde tijden door een vergelijking met andere ondernemingen in de branche te maken. Het kennen van zijn relatieve positie is van belang voor het beleid op langere termijn. Ook voor de accountantskosten, hoewel geen substantieel onderdeel van de kostprijs van het produkt van de onderneming, geldt dit. Toetsing in de praktijk blijkt tot op heden zeer moeilijk te zijn. Enigszins harde normen voor de hoogte van de accountantskosten bestaan er (nog) niet.

In de volgende paragraaf wordt nader ingegaan op één van de toetsingsmogelijkheden, namelijk de verhouding accountantskosten tot de omzet.

\section{Resultaten van een empirisch onderzoek naar de beheersing van (kosten van) accountantsonderzoek in Nederland}

De in deze paragraaf weergegeven resultaten zijn ontleend aan een in januari 1984 onder FINEM-leden in het kader van de FINEM-gespreksgroep 'Beheersing van (kosten van) accountantsonderzoek' gehouden enquête. Deze beoogde een eerste terreinverkenning op dit gebied voor Nederland. De leden van het FINEM vormen geen representatief beeld van het Nederlandse bedrijfsleven. Aan de verkregen onderzoeksresultaten kan derhalve slechts een indicatieve betekenis worden ontleend. Wij zijn evenwel van mening dat publicatie van de resultaten, ondanks het ontbreken van representativiteit, de discussie over het onderwerp kan bevorderen.

De onderzoekspopulatie bedroeg 111 ondernemingen. Van 50 ondernemingen is een reactie ontvangen. De verwerkbare response bedroeg 46 respondenten $(41,4 \%)$. 
De relatie van de omzet ten opzichte van de hoogte van de (totale) accountantskosten

Een vergelijking van haar accountantskosten met die van andere ondernemingen in de branche of omzetklasse geeft de ondernemingsleiding inzicht in de relatieve positie van de eigen onderneming. Deze kennis vormt een belangrijk basisgegeven voor de beheersing van de accountantskosten. Een dergelijke vergelijking is in Nederland (nog) zeer moeilijk. In Nederland bestaat namelijk - in tegenstelling tot bijvoorbeeld het Verenigd Koninkrijk - geen wettelijke verplichting tot publikatie van de externe accountantskosten in de jaarrekening. Op dit moment bestaan er nog geen harde normen voor de hoogte van de accountantskosten. Zoals in paragraaf 3 reeds is vermeld worden de accountantskosten veelal gerelateerd aan de omzet. In ons onderzoek is eveneens de omzet als maatstaf gehanteerd, mede om een vergelijking met buitenlandse onderzoeken op dit terrein mogelijk te maken. Door een nader onderzoek zou moeten worden vastgesteld of aan deze of een andere relatie (onder meer de verhouding accountantskosten tot bijvoorbeeld de vaste activa, tot de winst voor belastingen of tot een combinatie van maatstaven) een betrouwbare indicator voor de hoogte van de accountantskosten kan worden ontleend.

In tabel 5.1 zijn onze onderzoeksresultaten betreffende de verhouding van de accountantskosten en de omzet weergegeven. Wij beperken ons daarbij tot de kosten van de accountantscontrole. Uit deze tabel blijkt dat zowel de kosten van de externe accountant als die van de IAD in 1981 ten opzichte van die in 1980 evenredig met de omzettoeneming zijn gestegen, terwijl beide kosten in 1982 een grotere stijging c.q. een geringere daling hebben gekend dan de omzet.

Tabel 5.1: De kosten van de accountantscontrole als promillage van de omzet en geïndexeerd

\begin{tabular}{|c|c|c|c|c|c|c|}
\hline & \multicolumn{3}{|c|}{$\begin{array}{l}\text { Accountantskosten } \\
\text { als \% van de omzet }\end{array}$} & \multicolumn{3}{|c|}{$\begin{array}{l}\text { Accountantskosten } \\
\text { geindexeerd }(1980= \\
100)\end{array}$} \\
\hline & 1980 & 1981 & 1982 & 1980 & 1981 & 1982 \\
\hline $\begin{array}{l}\text { Kosten controle door de } \\
\text { externe accountant }\end{array}$ & 0,65 & 0,65 & 0,68 & 100 & 100 & 105 \\
\hline Kosten IAD & 0,56 & 0,56 & 0,58 & 100 & 100 & 104 \\
\hline Totale accountantskosten & 1,21 & 1,21 & 1,26 & 100 & 100 & 104 \\
\hline
\end{tabular}

Een vergelijking van de stijging van de externe accountantskosten met de prijsbeschikkingen voor accountantsdiensten toont aan dat er in 1981 sprake was van een volumestijging wat betreft de door de accountantskantoren aangeboden controlediensten. In 1982 hebben zij óf de toegestane prijsstijging niet ten volle doorgevoerd óf hun controlewerkzaamheden beperkt óf een combinatie van beide ontwikkelingen is van toepassing geweest. ${ }^{8}$

Voorts valt op te merken dat gedurende $1980 \mathrm{t} / \mathrm{m} 1982$ de verhouding tussen de externe en interne accountantskosten vrij constant is gebleven. Op het cijfermateriaal is voor elk van de drie jaren een Pearson produkt-moment 
correlatieberekening toegepast tussen de omzet en de totale accountantskosten. Over het geheel genomen blijkt de correlatiecoëfficiënt vrij hoog te zijn ( $\mathrm{R}$ circa .80). Gezien het feit dat er sprake is van een beperkte groep respondenten, heterogeen qua omzet en bedrijfstak samengesteld, dient bovenstaande hoge correlatiecoëfficiënt met de nodige voorzichtigheid te worden gehanteerd. Een nader onderzoek met een bredere opzet waarbij een aantal factoren, zoals onder meer omzet en bedrijfstak onder controle wordt gehouden zou een duidelijker licht moeten werpen op een dergelijke samenhang.

In tabel 5.2 zijn de respondenten ingedeeld naar vier omzetcategorieën. Per categorie zijn de accountantskosten (zowel die van de externe accountant als die van de IAD) weergegeven.

Tabel 5.2: De gemiddelde kosten van accountantscontrole in relatie tot de gemiddelde omzet voor de jaren $1980 \mathrm{t} / \mathrm{m} 1982$ per omzetcategorie

\begin{tabular}{lccc}
\hline $\begin{array}{l}\text { Omzetcategorie } \\
(\times f l)\end{array}$ & $\begin{array}{l}\text { Gemiddelde kosten } \\
\text { controle externe } \\
\text { accountant als pro- } \\
\text { millage van de ge- } \\
\text { middelde omzet }\end{array}$ & $\begin{array}{l}\text { Gemiddelde kosten } \\
\text { IAD als promillage } \\
\text { van de gemiddelde } \\
\text { omzet }\end{array}$ & $\begin{array}{l}\text { Gemiddelde totale ac- } \\
\text { countantskosten als } \\
\text { promillage van de ge- } \\
\text { middelde omzet }\end{array}$ \\
\hline tot 100 miljoen & 1,76 & 0,28 & 2,04 \\
100 miljoen & 1,77 & 0,90 & 2,67 \\
tot 1 miljard & 0,62 & 0,58 & 1,20 \\
1 tot 5 miljard & 0,40 & 0,47 & 0,87 \\
$>5$ miljard & & & \\
\hline
\end{tabular}

Er lijkt een caesuur te liggen tussen de omzetcategorie ' 100 miljoen tot 1 miljard' en die van ' 1 tot 5 miljard'. Hierbij is sprake van een sterke daling van zowel de externe als interne accountantskosten (als promillage van de omzet). De kosten van de IAD stijgen sterk bij de omzetcategorie ' 100 miljoen - 1 miljard' in vergelijking met de categorie 'tot 100 miljoen', hetgeen kan worden verklaard uit het feit dat er bij kleine ondernemingen niet of nauwelijks een IAD aanwezig is. Uit ons onderzoek blijkt dat $25 \%$ van de respondenten in de omzetcategorie 'tot 100 miljoen' een IAD heeft. Met name voor ondernemingen in de omzetcategorie ' 100 miljoen tot 1 miljard' vormt de IAD relatief een vrij hoge kostenpost.

Uit onderzoeksresultaten in de Verenigde Staten (Miller, p. 38) blijkt dat de gemiddelde kosten van de controle door een extern accountant $0,03 \%$ van de omzet is. Onderzoek van Wallace (1984a, p. 37) heeft uitgewezen dat voor ondernemingen met een omzet van meer dan 500 miljoen dollar deze kosten $0,04 \%$ van de omzet en voor ondernemingen met een omzet van minder dan 500 miljoen dollar bijna $2 \%$ van de omzet bedragen.

\section{Beheersing van accountantskosten}

De instrumenten die de ondernemingsleiding ter beschikking staan zijn grotendeels verbonden met de plannings- en beheersingscyclus welke toe- 
gepast wordt voor kosten (zie ook par. 4). Een aantal aspecten van deze cyclus is in ons onderzoek betrokken.

Het overleg tussen de ondernemingsleiding en de externe accountant.

$\mathrm{Bij} 57 \%$ van de respondenten vindt er regelmatig overleg plaats met de externe accountant ten aanzien van de controlewerkzaamheden. Deze respondenten leggen bijna alle $(85 \%)$ de daaruit resulterende afspraken schriftelijk vast, waarbij de volgende aspecten aan de orde komen:

- de taakverdeling tussen de interne en de externe accountant;

- de hoogte van de declaratie van de externe accountant;

- de jaarrekening en de daaruit voortvloeiende controlebevindingen.

Op de vraag of in de laatste drie jaar uit het overleg veranderingen van ingrijpende aard in de afspraken tot stand zijn gekomen geeft $42 \%$ van de respondenten te kennen dat dit niet het geval is geweest. De overige $58 \%$ heeft - als resultaat van het overleg - wijzigingen in de werkafspraken aangebracht. Deze aanpassingen hadden in hoofdzaak betrekking op de controletechnieken en het controleprogramma van de externe accountant en op de werkverdeling tussen de IAD en de externe accountant.

Bij $20 \%$ van de respondenten is het overleg gestructureerd in de vorm van een 'audit committee'. De samenstelling is per onderneming sterk wisselend. In alle gevallen heeft een lid van de Raad van Bestuur zitting in dit comité. Als leden van het audit committee worden door deze (beperkte) groep van respondenten voorts frequent genoemd een lid van de Raad van Commissarissen, het hoofd van de IAD en de externe accountant. Bij $33 \%$ van de respondenten is de externe accountant geen lid van het audit committee. Hier is dan sprake van een intern overlegorgaan.

Als taken van het audit committee worden vermeld de beheersing van de totale accountantscontrole (met als doel kostenminimalisatie), de bespreking van de jaarrekening, de controle-bevindingen, de bespreking van de 'management letters' en de resultaten van de follow-up daaromtrent en voorts de bewaking van het (onafhankelijk) functioneren van de IAD.

\section{Budgettering van de kosten van de controle door de externe accountant}

Budgettering is een belangrijk middel tot planning en beheersing van de accountantscontrole. Het is dan ook opmerkelijk dat bij $37 \%$ van de respondenten de externe accountants hun controlewerkzaamheden niet budgetteren. Dit heeft tot gevolg dat bij deze respondenten budgetonder- en overschrijdingen niet kunnen worden gesignaleerd en besproken met de ondernemingsleiding.

\section{Specificatie van de declaratie van de externe accountant}

Een ander belangrijk instrument bij de beheersing van de controle vormt een gedetailleerde declaratie van de externe accountant. Een declaratie die slechts een totaalbedrag laat zien geeft de ondernemingsleiding geen gedetailleerde informatie omtrent de werkelijke kosten van de controlewerkzaamheden. Hierdoor is het niet mogelijk dat deze werkelijke kosten in detail kunnen worden vergeleken met de gebudgetteerde kosten en dat op 
grond daarvan maatregelen ter verbetering kunnen worden genomen. Voorts kan een gespecificeerde declaratie aanknopingspunten geven om voor bepaalde controlegebieden tot een andere taakverdeling te komen tussen externe en interne accountant met daaraan gekoppeld een vermindering van de (externe) accountantskosten. Het is daarbij aan te bevelen dat de declaratie dezelfde indeling heeft als het budget.

De externe accountant geeft bij $28 \%$ van de respondenten geen specificatie van zijn declaratie naar advies- en controlewerkzaamheden.

Uit tabel 5.3, waarin de antwoorden op de vraag naar de detaillering van de declaratie ten aanzien van de controlekosten zijn vermeld, valt af te leiden dat de externe accountants in zeer geringe mate hun nota detailleren naar aard van de werkzaamheden, soort uren en daarbij behorende tarieven. Hieruit kan worden geconcludeerd dat de declaratie bij de respondenten niet of nauwelijks als beheersingsinstrument van de accountantskosten kan dienen.

Tabel 5.3: Specificatie van de rekening van de externe accountant

\begin{tabular}{|c|c|c|c|c|}
\hline \multirow[t]{2}{*}{ Specificatie van de rekening naar: } & \multicolumn{2}{|c|}{ Binnenland } & \multicolumn{2}{|c|}{ Buitenland } \\
\hline & $\begin{array}{l}J a \\
\%\end{array}$ & $\begin{array}{l}\text { Nee } \\
\%\end{array}$ & $\begin{array}{l}J \alpha \\
\%\end{array}$ & $\begin{array}{l}\text { Nee } \\
\%\end{array}$ \\
\hline Aard controlewerkzaamheden & 11 & 89 & 14 & 87 \\
\hline Soort uren (vennoot, medewerker, assistenten) & 4 & 96 & 14 & 86 \\
\hline Tarieven per soort uur & 11 & 89 & 11 & 89 \\
\hline
\end{tabular}

De rol en functie van de IAD

Een IAD komt bij $59 \%$ van de respondenten voor. Zoals is te verwachten komt zij het frequentst voor bij de grotere ondernemingen. In de omzetcategorie tot 100 miljoen heeft $25 \%$ een IAD. Voor de overige categorieën varieert het tussen de $50 \%$ en $75 \%$.

Het merendeel $(85 \%)$ van de diensten verricht werkzaamheden zowel op het terrein van de financial audit als van de operational audit. Van de interne accountantsdiensten houdt $11 \%$ zich uitsluitend met de financial audit bezig en $4 \%$ louter en alleen met de operational audit.

Op de vraag waarom een onderneming een IAD heeft zijn in hoofdzaak de volgende twee redenen genoemd:

- de behoefte van het (top)management aan een deskundig staforgaan waar alle audit activiteiten worden gecoördineerd;

- kostenoverwegingen, waarbij met name werd vermeld dat door het functioneren van een IAD de controlekosten van de externe accountant worden verminderd.

Verder werden door enkele respondenten de volgende argumenten genoemd:

- de positie van de IAD is historisch bepaald;

- de aard van de onderneming maakt het hebben van een IAD noodzakelijk;

- de IAD beschikt over een grotere kennis van de onderneming dan de externe accountant. 
Gezien de actuele ontwikkelingen (taakverandering c.q. afstoten van de IAD) bij een aantal Nederlandse ondernemingen is ook in de enquête gevraagd of de ondernemingsleiding voornemens is in de feitelijke situatie (het al of niet bezitten van een IAD) verandering aan te brengen. Daarnaast is naar de aard van deze verandering gevraagd.

Uit tabel 5.4 blijkt dat het merendeel der respondenten geen wijzigingen van de bestaande situatie ten aanzien van de IAD beoogt.

Tabel 5.4: Veranderingen in de situatie van de IAD binnen de onderneming

\begin{tabular}{|c|c|c|c|}
\hline \multirow{2}{*}{$\begin{array}{l}\text { Veranderingen in de situatie } \\
\text { ten aanzien van de } I A D\end{array}$} & \multicolumn{2}{|c|}{ Ondernemingen } & \multirow[t]{2}{*}{ Totaa } \\
\hline & Met IAD & Zonder IAD & \\
\hline Verandering & 8 & 2 & 10 \\
\hline Geen verandering & 17 & 17 & 34 \\
\hline $\begin{array}{l}\text { Het bezit van een IAD staat ter discussie bij de } \\
\text { onderneming }\end{array}$ & 2 & 0 & 2 \\
\hline Totaal & 27 & 19 & 46 \\
\hline
\end{tabular}

Als veranderingen worden door de acht respondenten met een IAD genoemd uitbreiding (3) c.q. inkrimping (2) van het takenpakket en afstoten (3) van de IAD. De beide respondenten zonder IAD geven als veranderingen aan de oprichting van een dergelijke dienst.

Bij het afstoten en inkrimpen van de IAD worden als motiveringen aangevoerd dat de IAD een relatief hoge kostenpost is en dat actuele ontwikkelingen - zoals het kritisch onder de loep nemen van de kosten en baten van een IAD - tot deze maatregel hebben geleid. Het uitbreiden en oprichten van de IAD wordt onderbouwd met het feit dat daardoor de procedures en interne controle beter kunnen worden bewaakt en dat de ondernemingsleiding in dat geval over een op auditgebied deskundig staforgaan beschikt. Tot slot werd in het enqueteformulier de mening van de ondernemingsleiding gevraagd omtrent de wijze waarop het beheersingsproces van de (kosten van) accountantswerkzaamheden in samenspel met de externe accountant functioneert. Uit de antwoorden daarop kwam naar voren dat bijna de helft $(48 \%)$ van de respondenten onteureden is over de wijze waarop het beheersingsproces van de externe accountantswerkzaamheden verloopt. Als belangrijkste redenen werden vermeld de ondoorzichtigheid van de declaratie en de ondoorzichtigheid van de inhoud van de werkzaamheden van de externe accountant.

De door de ondernemingsleiding gewenste resultaten van de accountantscontrole

In tabel 5.5 zijn de antwoorden op de vraag naar de wensen van de ondernemingsleiding met betrekking tot de controlewerkzaamheden van de externe accountant opgenomen. 
Tabel 5.5: Resultaten welke de ondernemingsleiding wenst van de controlewerkzaamheden van de externe accountant

\begin{tabular}{llc}
\hline Resultaat van de controlewerkzaamheden & $\begin{array}{c}\text { Ondernemingen } \\
\text { aantal }\end{array}$ \\
\hline $\begin{array}{l}\text { De (goedkeurende) verklaring van de externe accountant bij de con- } \\
\text { cernjaarrekening }\end{array}$ & 45 & $98^{*}$ \\
De management letter bij de concernjaarrekening & 30 & 65 \\
$\begin{array}{l}\text { De (goedkeurende) verklaring van de externe accountant bij elke af- } \\
\text { zonderlijke jaarrekening van de dochters c.q. werkmaatschappijen }\end{array}$ & 23 & 50 \\
$\begin{array}{l}\text { De management letter bij elke afzonderlijke jaarrekening van de doch- } \\
\text { ter- c.q. werkmaatschappijen }\end{array}$ & 19 \\
$\begin{array}{l}\text { Een mondelinge bespreking of schriftelijke vastlegging van (eventueel) } \\
\text { door de externe accountant gesignaleerde probleemgebieden welke geen } \\
\text { betrekking hebben op het functioneren van de administratieve orga- } \\
\text { nisatie }\end{array}$ & 24 \\
$\begin{array}{l}\text { Aanbevelingen ten aanzien van de gesignaleerde probleemgebieden } \\
\text { welke geen betrekking hebben op het functioneren van de administra- } \\
\text { tieve organisatie }\end{array}$ & 16 \\
$\begin{array}{l}\text { Een mondelinge bespreking of schriftelijke vastlegging van de overige } \\
\text { resultaten van de controlewerkzaamheden van de externe accountant }\end{array}$ & 27 \\
\hline
\end{tabular}

* Eén van de ondernemingen is een dochter van een andere onderneming en behoeft als zodanig geen verklaring van de externe accountant bij haar jaarrekening.

\section{Slotbeschouwing}

In dit artikel zijn - vanuit de optiek van de ondernemingsleiding - enkele aspecten betreffende de problematiek van de beheersing van de (kosten van) accountantscontrole behandeld.

In het laatste decennium valt er in Nederland, zowel in de praktijk als in de theorie, een belangstelling voor dit onderwerp te constateren. Deze belangstelling is met name afkomstig van de ondernemingsleiding in het kader van de beheersing van de management-afhankelijke kosten. Ten aanzien van de markt voor accountantscontrole werd voorzichtig geconcludeerd dat deze markt, voor zover betrekking hebbende op ter beurze genoteerde ondernemingen, oligopolistische kenmerken bezit. De hoogte van de accountantskosten op deze markt wordt beïnvloed door een aantal factoren die zijn in te delen in algemene, ondernemingsbepaalde en accountantsbepaalde factoren, waarbij valt op te merken dat de laatste twee categorieën de hoogte van deze kosten het sterkst bepalen. Voorts wordt bovengenoemde markt gekenmerkt door een grote mate van beslotenheid. Een organisatie die op een dergelijke markt als aanbieder opereert heeft geen direct belang bij kostenverlagingen, waardoor een drang tot efficiencyverbetering, innovatie van controletechnieken, en dergelijke ontbreekt. Verder werkt het marktmechanisme onvoldoende om een waarborg te verschaffen voor een acceptabele prijs/kwaliteitverhouding van het produkt van de accountant, de algemene controle.

De ondernemingsleiding is gebaat bij een evenwichtige prijs/kwaliteitverhouding ten aanzien van de accountantscontrole. Bovendien zal zij invloed op die kosten willen uitoefenen en de kosten en de kwaliteit wensen te bewaken en beheersen. Een nuttige rol kan hierbij vervullen de met betrek- 
king tot andere kosten veelal reeds toegepaste beheersings- en planningscyclus. Mede in dit kader is het noodzakelijk indien zij over een 'yardstick' kan beschikken voor de hoogte van de kosten van de accountantscontrole. Uit ons onderzoek onder FINEM-leden naar de stand van zaken omtrent de beheersing van accountantscontrole kwam naar voren dat de gemiddelde totale accountantskosten voor de kleine ondernemingen (naar omzet ingedeeld) als promillage van de omzet hoger zijn dan bij de grote ondernemingen. Of en in hoeverre de omzet of een andere maatstaf een betrouwbare norm is voor de hoogte van de accountantskosten zou door nader onderzoek aan het licht gebracht moeten worden. Een bepaling van deze 'norm' per bedrijfstak zou de waarde ervan voor de ondernemingsleiding kunnen versterken.

Regelmatig overleg en een strakke budgettering zijn onontbeerlijk voor een goede beheersing van de accountantscontrole. Budgetverschillen dienen dan ook door de accountant en ondernemingsleiding gezamenlijk te worden geëvalueerd als sluitstuk van de beheersingscyclus. Om deze plannings- en beheersingscyclus daadwerkelijk succesvol te laten verlopen is het noodzakelijk dat de controlerend accountant meer inzicht verschaft in zijn handelen, in zijn organisatie en in zijn tarievenopbouw. Onze onderzoeksresultaten wijzen uit dat de controlerende accountants met name het laatste (inzicht in de tarievenopbouw door middel van hun declaratie) in zeer geringe mate verschaffen. Hieruit kan geconcludeerd worden dat de declaratie niet of nauwelijks als beheersingsinstrument van de accountantskosten kan fungeren en dat de ondernemingsleiding geen goed oordeel kan vormen omtrent de prijs/kwaliteitverhouding van de accountantscontrole.

Het is dan ook niet verwonderlijk dat bijna de helft van de respondenten ontevreden is over de wijze waarop het beheersingsproces van de (kosten van) accountantswerkzaamheden in samenspel met de externe accountant functioneert.

De externe accountants zouden dan ook meer aandacht moeten gaan besteden aan beheersingsaspecten zoals budgettering en regulier overleg met de ondernemingsleiding met betrekking tot de algemene controle en hun declaraties specificeren naar tarieven per soort uren en werkzaamheden. Dit zal tot gevolg hebben dat de ondernemingsleiding meer invloed kan uitoefenen op haar accountantskosten en dat de gesignaleerde ontevredenheid zal verminderen.

\section{Geraadpleegde literatuur}

Bak, G. G. M., H. C. Dekker en H. P. A. J. Langendijk (red.), Beheersing van (kosten van) accountantscontrole, Kluwer/NIVE/FINEM, 1985.

Bavishi, V. B. and H. E. Wyman, Who audits the world: trends in the worldwide auditing profession, Storrs, Center for transnational accounting and financial research, 1983.

Beylevelt, J. C. en F. W. Vlotman, Beheersingssystemen voor management-afhankelijke kosten, Kluwer/NIVE/FINEM, 1985.

Briston, R. and R. Perks, External auditor - his role and costs to society, Accountancy, November 1977 , p. 48-50, 52 .

Dekker, H. C. en H. P. A. J. Langendijk, Beheersing van accountantscontrole en accountantskosten, Tijdschrift Financieel Management, 1985/5, p. 6-19. 
Dekker, H. C. en H. P. A. J. Langendijk, Verslag van de enquête 'Beheersing van (kosten van) accountantsonderzoek', Working paper 85-1, Vakgroep Bedrijfseconomie, Universiteit van Amsterdam, (niet gepubliceerd).

Frielink, A. B., De GBR verklaard, Stenfert Kroese BV, Leiden, 1984.

Francis, J. R., The effect of audit size on audit prices. A study of the Australian Market, Journal of Accounting and Economics, 1984/6, p. 133-151.

Francis, J. R. and B. M. Pollard, Investigation of non audit fees in Australia, Abacus, December 1979, p. 136-144.

Garner, D. E., Corporate audit costs, The internal auditor, October 1980, p. 42-49.

Gilling, D. M. and P. J. Stanton, Changes in the Structure of the Auditing Profession in Australia, Abacus, June 1978, p. 68-80.

Hobgood, G. and J. A. Sciarrino, Management looks at audit services 1 en 2, Financial Executive, April 1972a, p. 26-32 en August 1972b, p. 24-25.

Huys, A., De accountant: noodzakelijk kwaad of behulpzame deugd?, Management Totaal, oktober 1983 , p. 51-53, 59 .

International Accounting Bulletin, Country Focus - The Netherlands: Dutch firms venture out from audit base, May 1985, p. 8-11.

Lothian, N., Audit and the fee: views from the boardroom, Accountant's Magazine, April 1983a, p. 135-140 en May 1983b, p. 180-183.

Miller, D. E., Annual audit revisited, Financial Executive, March 1978, p. 38-44.

Pound, G. D., and J. R. Francis, Accounting services market: theory and evidence, Journal of Business Finance and Accounting, Autumn 1981, p. 353-371.

Schreuder, H., Regelgeving ten aanzien van niet-financiële informatie, Maandblad voor Accountancy en Bedrijfshuishoudkunde, bijzonder nummer 'Regelgeving voor de jaarrekening; een internationale vergelijking', mei/juni 1981, pag. 334-348.

Simunic, D. A., Pricing of audit services: theory and evidence, Journal of Accounting Research, Spring 1980, p. 161-190.

Taylor, M. E., and R. L. Baker, Analysis of the external audit fee, Accounting and Business Research, Winter 1981, p. 55-60.

Wallace, W. A., External audit fees: how reasonably are they? Financial Executive, January 1984a, p. 34-35, 37-39.

Wallace, W. A., Internal auditors can cut CPA costs, Harvard Business Review, March-April 1984 b, p. 16, 20.

\section{Noten}

1 Pound and Francis (p.368) concluderen voor Australië dat de markt van de accountantscontrole 'displays many features of a mature oligopoly'. Simunic ( $p$. 187) constateerde voor de Verenigde Staten dat '. . price competition prevails throughout the market for audits of publicly hold companies cannot be rejected'. Zijn onderzoek wees uit dat de honoraria van de Big Eight lager waren dan die van de niet-Big Eight. Hij concludeert dat de schaaleffecten van de Big Eight in de vorm van lagere honoraria worden doorgegeven aan de cliënten.

2 In de USA is in een onderzoek onder de leden van het Financial Executive Institute naar de relatie onderneming-accountantskantoor een poging ondernomen om de hoogte van de extra accountantskosten, die redelijkerwijze konden worden toegeschreven aan publicatievoorschriften van de SEC vast te stellen (zie Miller). In zijn bijdrage aan het bijzondere $M A B$-nummer 'Regelgeving voor de jaarrekening; een internationale vergelijking' geeft Schreuder een overzicht van de kosten van regelgeving betreffende niet-financiële informatie in de Verenigde Staten (p. 342).

3 In zijn artikel maakt Garner evenwel melding dat de door hem verzamelde gegevens erop wijzen dat de accountantskosten variëren met drie factoren: de omzet, de bedrijfstak waarin een onderneming opereert, en de samenstelling van de activa ( $p .45$ ).

4 Lothian (1983) gebruikte de ratio gemiddelde accountantskosten/gemiddelde winst voor belasting.

5 Ten aanzien van de identiteit van de accountant signaleert Francis, (p. 148) dat de grotere accountantskantoren in Australië hogere honoraria berekenen. Op basis van zijn toetsingen concludeert Francis dat er in Australië ondersteuning voor de veronderstellingen kan worden gevonden dat er produktdifferentiatie bestaat. Simunic ( $p .187)$ signaleert voor de USA dat de gemiddelde accountantskosten van de grotere accountantskantoren lager waren dan die van de kleinere kantoren. Hij meent dat de hypothese dat de markt voor accountantscontrole wordt beheerst door prijsconcurrentie niet kan worden verworpen. Zijn onderzoeksresultaten suggereren dat 'the Big Eight firms enjoy scale economies which are passed on as lower prices to auditees' ( $p .188$ ).

6 Deze grote accountantskantoren kunnen op de deelmarkt van de kleine ondernemingen blijven opereren, mits zij eenzelfde functie voor die ondernemingen vervullen als de kleinere 
accountantskantoren en een tariefdifferentiatie (in de vorm van lagere tarieven) toepassen. 7 In de USA is de mate van specialisatie en differentiatie van accountantskantoren bekend. Men weet daar welk (groot) accountantskantoor zich toelegt op banken, wie op grote industriële ondernemingen, op non-profitorganisaties, op grote reclamebureaus en dergelijke. Een eerste overzicht voor de Nederlandse situatie dienaangaande vindt men in het International Accounting Bulletin van mei 1985.

8 De prijsbeschikking bedroeg voor 1980 0\%, voor 19815 a $6 \%$ en voor $198271 / 2 \%$ als toegestane prijsverhoging. Voorts veronderstellen wij in ons artikel dat het pakket van controlediensten dat in 1980 werd verricht in 1981 en 1982 qua inhoud niet is veranderd. 